A. Abbasov,

Director, Azerbaijan Scientific-Research and Designed-Prospecting Institute of Energetics, under the "Azerenergy" JSC, Baku, Azerbaijan

ORCID ID: 0000-0003-0972-1413

DOI: $10.32702 / 2306-6814.2020 .21-22.48$

\title{
ELECTRICITY MARKET ESTABLISHMENT AND ITS CURRENT SITUATION IN EUROPE
}

\author{
Аббасов Алі Яшар огли, \\ Аиректор, Азербайджанский Научно-Исследовательский и Проектно-Изыскательский \\ Институт Энергетики при АО "Азерэнержи", Баку, Азербайджан
}

Usage of electricity is drastically differ today that it was first introduced. With development and industry, technology and raise of world population created new challenges and needs. Before he establishment of electricity markets, the industry was long been regulated by utility companies that had control the overall production, transmission and sales. Vertically integrated systems had one producer that managed the whole process and prices mainly regulated by the tariffs set by authorities. However, shifting from traditional method to a market theme has opened a new page in electricity industry. Thus, deregulated markets started to introduce split independent players such as producers, transmission companies and consumers. Starting from the 1980's enormous changes occurred in this field which reshaped today's electricity liberal markets. Moreover, electricity itself changed from being only commodity to a financial exchange instrument. Electricity Markets definition itself is still considered a new terminolody in some parts of the world it's been in use for several decades in other parts. Liberal power markets brought new competition and higher utilization to the sector. Investors started to show interest in energy production, transmission and trades. Europe is one of the pioneers who implemented new liberal electricity markets shifting from traditional one. Nowadays, there electricity trades happen using three main channels: bilaterla agreements, physical markets, and financial markets. Bilateral agreements is the one that has the highest trade volumes among three. It is separate from regulated market conditions, and happen among the sellers and buyers based on agreements. Unlike bilateral contract, physical markets or spot market is regulated by dealers. Finally, financial markets of electiricyt is similar to derivatives markets use financials for trading. This article illustrates market integration, inter-market relations using experiences of European countries. The aim of this articke to briefly discuss the points of successfull market integration.

Використання електрики сьогодні сильно відрізняється від того, яким воно було з моменту виникнення. Розвиток промисловості, технологій і зростання населення світу створили нові проблеми і потреби. До створення ринків електроенергії галузь тривалий час регулювалася комунальними підприємствами, які загалом контролювали виробництво, передачута продаж. У вертикально інтегрованих системах один виробник керував усім процесом, а ціни в основному регулювалися тарифами, що встановлюються владою. Однак перехід від традиційного методу до ринкового відкрив нову сторінку в електроенергетиці. Таким чином, на дерегульованих ринках почали з'являтися окремі незалежні гравці, такі як виробники, передавальні компанії та споживачі. Починаючи з 1980-х років у цій галузі відбулися величезні зміни, які змінили сьогоднішні ліберальні ринки електроенергії. Більш того, сама електроенергія з простого товару перетворилася на інструмент фінансового обміну. Саме визначення "Ринки електроенергії"до сих пір вважається новим терміном у деяких частинах світу, воно використовується вже кілька 
десятиліть у багатьох країнах світу. Ліберальні енергетичні ринки принесли в сектор нову конкуренцію і більш високий рівень використання. Інвестори почали проявляти зацікавленість до

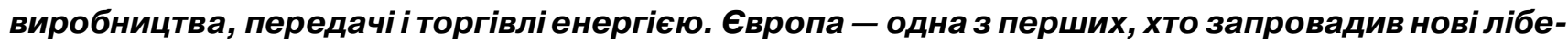
ральні ринки електроенергії, відмовившись від традиційних. Нині торгівля електроенергією здійснюється за трьома основними каналами: двосторонні угоди, фізичні ринки і фінансові ринки. Двосторонні угоди - це ті, за якими обсяги торгівлі є найвищими з трьох вищевказаних. Це відбувається окремо від регульованих ринкових умов і відбувається між продавцями і покупцями на основі угод. На відміну від двосторонніх контрактів, фізичні ринки або спотовий ринок регулюються дилерами. Нарешті, фінансові ринки електрики схожі на ринки похідних фінансових інструментів, які використовують такі інструменти для торгівлі. Ця стаття ілюструє ринкову інтеграцію, міжринкові відносини, використовуючи досвід європейських країн. Мета статті коротко обговорити моменти успішної ринкової інтеграції.

Key words: ENTSO-E, liberal electricity markets, market integration, electricity exchanges.

КлючоВі слоЪа: ENTSO-E, ліберальніринки електроенергії, ринкоВа інтеграція, біржі електроенергії.

\section{INTRODUCTION}

The market is where buyers and sellers meet and exchange takes place and thus the price is formed. Fetter (1924) defines the market as the place where many buyers and sellers trade under conditions similar to perfect competition. In perfect competition, each participant assumes that the market price is formed independently of his or her actions. In perfect competition, market participants are price takers and cannot affect the market price. Therefore, the perfect competition assumption makes sense only when there are many companies that have small shares in the market and produce exactly the same product. Since firms cannot affect the market price by changing the amount they supply, profit maximization depends on the amount of production. Every form of market in which the assumption of perfect competition does not materialize is a type of imperfect competition markets. The most contrasting market form to the perfect competition market is the monopoly where one firm dominates the entire market. If a company can produce a product cheaper than other companies with its cost and scale structure, it will be the only manufacturer in that market. Unless other companies produce at these costs, it remains the only producer in the market. These types of monopoles are called natural monopoles.

Electricity markets had such a structure until the liberalization process that continues today. Since the early 1990 s, in the electricity industry, which traditionally has a state-controlled monopoly structure, there have been reforms aimed at the separation of the vertically integrated monopoly structure that governing generation, transmission, distribution and retail together, and the liberalization of markets to gain a competitive character. There are three main tools of reforms to ensure efficiency in markets: free access to the network, restructuring and deregulation [7].

The parts of the electricity industry that can be opened up to competition are the generation, wholesale and retail markets. Natural monopoly structure continues in transmission and distribution networks and their operation. The transmission and distribution networks that enable the generated electricity to reach the end consumer are structures that cover wide geographies and whose installation involves high investment costs. Since the establishment of alternative network structures will not be economically and environmentally effective, transmission and distribution are operated over a single network. That is, the natural monopoly structure continues at the regional or national level in transmission and distribution [7]. However, these stages are subject to intensive regulation in order to ensure and protect the conditions of competition throughout the industry. Thus, it is tried to prevent the abuse of market power by incumbent companies and to ensure fair access of all market participants to the transmission and distribution networks. For this purpose, the operation of the network system is carried out by an independent system operator.

In a vertically integrated monopoly structure, a single company manages the production, transmission, distribution and sale of electricity to the end consumer. The company's field of activity can be a region or a city, or it can be a whole country. Early regulations to give the electricity markets a competitive edge focused on the decoupling of this vertically integrated structure and fair access of third parties to the grid.

Despite small differences, the motivation behind the liberalization of energy markets around the world has common ideological and political reasons. Especially, the expectation that the success achieved by liberalization in other markets can also be achieved in the energy sector and the need for the division of the monopoly structure. Despite small differences, the motivation behind the liberalization of energy markets worldwide has common ideological and political reasons. Especially, it can be mentioned that the success achieved by liberalization in other markets can be achieved in the energy sector and the need for the division of the monopoly structure. The competitive structure is expected to trigger technological innovations in the sector and increase economic efficiency [11]. However, the disruption of the monopoly structure has been possible with changes and developments in production, transmission and distribution technologies. In the electricity industry, this structure of the production process, which was accepted as a natural monopoly due to the economies of scale that required the use of large generation plants until the 1990s, could be disrupted as a result of the economic activity achieved by smaller generation plants thanks to new generation technologies. However, developments in information technologies and the operation of transmission 
Table 1. list of power exchanges in Europe

\begin{tabular}{|l|l|l|l|}
\hline \multicolumn{1}{|c|}{ Title } & \multicolumn{1}{|c|}{ Involved countries } & Established & $\begin{array}{c}\text { Trade } \\
\text { volume } \\
\text { TW }\end{array}$ \\
\hline APX Power NL & The Netherlands & 1999 & 44 \\
\hline APX Power UK & UK & 2000 & 62 \\
\hline Belpex & Belgium & & 24 \\
\hline BSP Southpool & Austria, Italy, Slovenia & 2008 & 6 \\
\hline EEX & Germany & 2002 & 2537 \\
\hline EPEX Spot & $\begin{array}{l}\text { Austria, Belgium, France, Germany, } \\
\text { Luxembourg, UK, the Netherlands, Switzerland }\end{array}$ & 2008 & 566 \\
\hline EPIAS & Turkey & 2015 & 99 \\
\hline EXAA & Austria, Germany & 2001 & 8 \\
\hline EXIST & Turkey & 2015 & 152.32 \\
\hline GME & $\begin{array}{l}\text { Austria, France, Greece, Italy, Malta, Slovenia, } \\
\text { Switzerland }\end{array}$ & & 312 \\
\hline HEnEX & Greece & 2018 & \\
\hline HUPX & Hungary & 2010 & 22 \\
\hline IBEX & Bulgaria & & \\
\hline Nordpool Spot & $\begin{array}{l}\text { Denmark, Estonia, Finland, Germany, Latvia, } \\
\text { Lithuania, Norway, Sweden, UK }\end{array}$ & 489 & \\
\hline OTE & Czech Republic & 2001 & 20 \\
\hline OMIP & $\begin{array}{l}\text { Netherlands, Malta, Belgium, Cayman Island, } \\
\text { Denmark, Luxembourg }\end{array}$ & 2006 & 30 \\
\hline OPCOM & Romania & 2000 & 85 \\
\hline powernext & france & 2001 & 1024 \\
\hline PXE & $\begin{array}{l}\text { Czech Republic, Hungary, Poland, Romania, } \\
\text { Slovakia }\end{array}$ & 2007 & 24 \\
\hline TGE & Poland & 1999 & 186 \\
\hline & & & \\
\hline
\end{tabular}

Source: Next Kraftwerke https://www.next-kraftwerke.com/knowledge/power-exchanges-list

and distribution networks played an important role in decoupling the vertically integrated structure in generation, transmission and distribution. Thus, it has been possible to open the production, wholesale and retail markets to competition in the electricity industry.

\section{ELECTRICAL INDUSTRY MODELS}

Four basic models have been identified regarding the structure of the electricity industry: Monopoly, Single Buyer Model, Wholesale Competition, Retail Competition. Until the electricity industry reforms, the first model prevalent worldwide is a vertically integrated monopoly industry structure with no competition. All sequential market activities from the generation of electricity to the sale to the end consumer are carried out by a single firm [7].

In the single-buyer (purchasing agent) model, competition is only allowed in the electricity generation phase. New production capacities are free to participate in the market. However, there is only one authority in the purchase of electricity from the producer. This institution negotiates with producers on behalf of all registered consumers. That is, at this stage, price formation takes place on a competitive principle. After the sale is realized, the electricity is sold to the suppliers who will provide the distribution at an updated tariff. Electricity is delivered to the end consumer by the supplier company. At this stage, the consumer has no chance to choose the supplier company. Retail prices do not form as a result of the functioning of the market mechanism. In other words, there is a monopoly structure in the distribution phase. However, the model is advantageous at the initial stage of reforms due to its simplicity [7].

Another more developed form of market is competitive wholesale markets. In such markets, manufacturers and distributors (retailers) or large users are in exchange without a mandatory intermediary institution. Since the wholesale market is open to many buyers, a more realistic competition can be mentioned. On the other hand, in the retail sales phase, the consumer does not have the opportunity to choose the retailer to buy electricity [7].

In markets where the retail market operates in a competitive manner, consumers have the opportunity to choose the company from which they will purchase electricity. Like the wholesale market, the retail market operates with the market mechanism [7]. Of course, building such a market requires a specialization process both physically and in terms of training market participants. Another difficulty of such markets is that they require some strict regulations to protect the consumer [7].

During the starting phase of the liberalization process in the European electricity markets, electricity trading only realized with bilateral agreements and in over-the-counter markets. Bilateral agreements allow traders to trade without any exchange markets. Following the period when the first electricity directive was implemented, electricity exchanges started to be established in several European countries and started from 2016, pooled wholesale electricity markets organized. In electricity exchange markets, electricity trades in spot markets, intraday markets and in derivatives markets.

European Electricity Exchanges

Nord pool that includes Scandinavian and Baltic countries is the first multinational organized electricity market in the Europe. Unlike NETA (New Electricity Trading) in England and Wales, participation is not a mandatory even though it is a pooled market. Nord Pool managed to organize the largest international electricity market by adding Sweden in 1996, Finland in 1998, Denmark in 1999, Estonia in 2010, Lithuania and Latvia in 2013 to its pool. Nord Pool has 380 members and its trade volume reached 485 TWh in 2015 (table 1). Electricity 
markets are still insufficient within Baltic countries and their connection with the rest of the European countries. It also has to be mentioned that, Estlink 1 and Estlink 2 lines between Estonia and Finland, LitPol Link lines between Lithuania and Poland, Nordbalt lines between Lithuania and Sweden enormously increased the interconnections of Baltic countries with another European countries. Baltic Energy Market Action Plan (BEMIC) which mainly focuses on integration of Baltic countries to Europe and increasing the transmission lines, have been agreed in 2009 and started to be implemented since 2011. Litpol Link and Nordbalt transmission lines have been planned and realized within this plan. In the scoop of 2015 Energy Supply Security Declaration liberal, competitive, transparent and efficient energy markets have been targeted. Additionally, the declaration aimed to realize integration and synchronizing with European countries.

The first organized electricity market in Europe was established in 1990 in England and Wales. The electricity market of England and Wales, which was designed as a pool model, was replaced by electricity exchanges in 2001 with the entry into force of NETA (New Electricity Trading Agreement). APX Power UK was founded in 2000 and is the UK's first independent electricity exchange. In 2003, both APX-UK and UKPX were active in England and Wales. With the entry into force of BETTA (British Electricity Trading and Transmission Agreement) in 2005, Scotland also joined the UK electricity market. In the UK, unlike other electricity markets in Europe, bids are structured in half-hour blocks rather than hourly blocks. The number of registered members of APX_UK in 2020 is 62; The trade volume was 62 TWh (Table 1 ). The UK and Dutch electricity markets are linked by the transmission line, which was completed in October 2010 and went into operation in April 2011. The first transmission line connecting the UK and French electricity markets is a $160 \mathrm{MW}$ line built in 1961. Since this line was insufficient to meet the needs, it was replaced with a new $2000 \mathrm{MW}$ system in 1975-1986. In November 2016, the transmission capacity of the line was reduced by half when a ship anchor damaged the cables during the Angus Storm.

The transition of the electricity markets to competition in the Netherlands started in 1989, but the real changes took place in 1995 and 1998. APX Power Netherlands (APX_NL) was established in 1999 based on the Nord Pool model. In October 2010, the APX group merged with the Belgian electricity exchange Belpex.

After the merger of APX and EPEX SPOT in 2015, EPEX SPOT became Europe's largest international electricity exchange. Until now, EPEX SPOT is Europe's second largest international electricity exchange, covering Germany / Austria, Luxembourg, France and Switzerland. In 2020, it had a total of 415 members and 566 TWh of trade (Table 1).

The electricity market in Germany was opened to competition in 1998. The trade that took place in the overthe-counter markets with bilateral agreements until the middle of 2000 was transferred to the organized market with the establishment of APX DE in May, LPX in June and EEX in August. APX_DE closed in December 2000; LPX and EEX merged in 2002.
The deregulation of the electricity markets in France started in 2000, but the transition to competition took place at the end of 2001. The French electricity exchange Powernext was established in November 2000 with the support of NordPool. In September 2008, EPEX SPOT was created with $50 \%$ EEX and $50 \%$ Powernext support. Powernext in January 2009; EEX was transferred to EPEX SPOT in September 2009.

In April 2015, the APX group which included Belpex, merged with EPEX SPOT, thereby covering centralwestern Europe and the UK region. Since the end of 2016, it has been operating under the name EPEX SPOT.

The Spanish electricity exchange OMIE (OMEL) was established in 1997 with a mandatory participation. OMIE, which started its operations in Spain in 1998, covers the entire Iberian Peninsula since 2007 and is currently operated in accordance with the Nord Pool model. As of $2016,80 \%$ of the electricity supply in Spain and Portugal is traded in OMIE. Geographically separated from the rest of Europe, the Iberian Peninsula was connected to France with the Inelfe transmission line, which was decided in 2008 and the construction was completed in February 2015. This line, which provides the electricity trade between Spain and France, started commercial operation as of October 2015. In the electricity markets, the foreign trade balance of countries varies from year to year due to market coupling, cross-border transmission network capacity constraints and price fluctuations. The foreign trade balance of electricity markets (exchanges) is the balance between physical electricity input and output in countries. The balance in the physical electricity flow and the balance of commercial transactions (export and import difference) are generally not equal in a system where the physical electricity flow is provided by interconnection between the two countries (ENTSO-E, 2015).

Unless there is a capacity constraint in the electricity trade between the regions, a single price is formed in the system. In this case, the entire regions can be evaluated as a single market. If the transmission network capacity between the regions is insufficient, a separate equilibrium price will occur in each market in the absence of trade between regions. If the trade between the regions exceeds the transmission network capacity, market splitting will occur. In this case, the system operator (TSO) can perform arbitrage trade from the low price zone to the high price zone by using the capacity of the line to the maximum. Market price occurred as a result of this will be lower less than the average of prices that will occur when markets are balanced separately [1].

TSO's profit obtained from arbitrage trade is called the "Constraint Management Fee" or the "Congestion rent". If electric current transmitted from region $B$ to region A is $f_{B-A}$ provided that $P_{A}>P_{B}$, TSO's profit is $\left(P_{A}-P_{B}\right) f_{B-A}$. This gain can be utilized in a way that contributes to increasing social welfare by transferring it to transmission network capacity investments or by sharing it among system users. On the other hand, TSO can also apply an optimization approach based on market balancing and market price formation separately. In European electricity markets, the market segregation method is applied in the North Pool. Accordingly, for example, while different prices may occur in each price zone determined according 
to transmission network constraints in Sweden, it is possible for a single price to be formed in the remainder of the North pool.

In market matching, instead of dividing the market into sub-regions, more than one market is treated as a region connected by interconnections. In fact, transmission network capacity management applied in market divergence is also applied in market matching.

In market segregation, the fact that market participants only bid for the region they are affiliated to provides various advantages in terms of market operation. However, its implementation for networks covering a wide geography is difficult as it requires a structure that governs the transmission network capacity management of all price zones together [1].

Hence, the solution carried out for the integration of electricity markets in Europe is based on market matching. Examples of market matching include the central-western European region that includes France, Belgium, Germany / Austria and the Netherlands. Here, each country is a separate market that is part of a whole.

The fact that the right to access the cross-border transmission network is based on the auction between market participants creates an opportunity for arbitrage between markets. Short-term arbitrage supports price convergence and therefore market integration. On the other hand, as in North Pool, an approach that simultaneously clears the electricity markets and is based on optimization of transmission network sharing also supports the integration of markets.

Transmission network constraints are a factor that strengthens the fragmented structure of electricity markets and therefore the market power of producers in the region. In this context, market matching makes important contributions to the formation of a competitive market environment. With market matching, the number of firms competing in the market increases, and the opportunities for incumbent firms to apply market power are restricted. Here, it is important to target the independence of the system operator and the level of efficiency that maximizes social welfare in balancing the market. The efficiency level that can be achieved by market matching can be realized below the theoretical level due to differences in market design of participating markets, energy policies and the authority and responsibility of regulatory boards. Therefore, the success of market matching and therefore the construction of a fully integrated market depends on the harmonization of differences at national level or the establishment of an inclusive legal framework across Europe [1].

Market matching provides more competitive results in the market. However, market integration will increase the likelihood of competitive results. Market integration implies that the opportunities for firms to exercise market power are not possible, that firms compete in a single integrated market, not in discrete markets. Thus, market power wil depend not on the shares of firms in their national markets but on their share in the integrated market, which will reduce the market power of firms in national markets.

Price Matching Zones (PCR)

Price Matching Zones (PCR) is a market matching solution initiated by European electricity exchanges to be implemented across Europe.A common algorithm that takes into account the capacity constraints of the transmission network is applied in the calculation of day ahead electricity prices in PCR member markets. Centralwestern Europe (CWE), central-eastern Europe (CEE), central-south Europe (CSE), South-western Europe (SWE), France-United Kingdom-Ireland (FUI), Baltic and Scandinavian (Northern Europe) within the framework of PCR 7 regions are defined as NE) regions. Accordingly, the regions defined and the countries within the relevant region are as follows:

- CWE: Germany / Austria, Belgium, France, Netherlands, Switzerland, Luxembourg.

- CEE: Germany / Austria, Czech Republic, Poland, Hungary, Slovenia, Slovakia.

- CSE: Germany / Austria, France, Italy, Slovenia, Greece.

- SWE: France, Spain, Portugal.

- FUI: France, UK, Ireland.

- Baltic: Estonia, Lithuania, Latvia.

- NE: Sweden, Norway, Denmark, Finland.

The PCR initiative started in 2009, the parties signed their partnership agreement in June 2012. An important component of the PCR project was the development of a common price matching algorithm called EUPHEMIA (Pan-European Hybrid Electricity Market Integration Algorithm).

Originally developed for the Belgian electricity exchange Belpex, COSMOS was expanded into the CWE region in 2010 and became a pioneer in the development of EUPHEMIA. EUPHEMIA is an algorithm that solves the market coupling problem in day-ahead electricity markets within the framework of PCR. With EUPHEMIA, supply and demand are balanced for every period of the day in dayahead electricity markets and market price. While calculating, the structural features of participating markets and transmission network capacity constraints are also taken into account. The algorithm calculates the market price, net positions and interregional electricity by processing the purchase and sale offers given to participating markets (national or regional). However, as a result of optimization, it is also possible for different prices to occur in different price zones. In case of price differences between EUPHEMIA and neighboring markets, an optimization problem designed to ensure full capacity utilization of the transmission network is solved. The most important advantage of EUPHEMIA over other algorithms, which is its predecessor, is that it can combine not only markets with the same or similar characteristics but also markets with different requirements under a single algorithm.

In this way, market matching can be successfully applied in regions with different market designs; Inefficiencies arising from national differences are minimized. The three main objectives of EUPHEMIA are listed as creating competitive prices in the market, improving public welfare and ensuring efficient allocation of capacity [4].

When compared to the market, the maximization of social welfare is achieved by comparing the demand and supply of electricity. In intermarket transmission, more consumers and producers coincide, but there is 
less consumer or producer surplus. EUPHEMIA optimizes social welfare defined as a function of consumer surplus producer surplus and constraint return variables to be greater than or at least equal to the scenario of no electricity transfer between markets [4].

In February 2014, the PCR project was expanded to include the Central Western Europe (CWE) and UK electricity markets as well as the Nordic and Baltic electricity markets (Nord Pool). Thus, the price matching region defined was named as North-West Europe (NWE). EUPHEMIA was first introduced in the NWE region. In May 2014, the South-western European region (SWE) matched with the NWE, with the participation of the Spanish and Portuguese electricity markets (OMIE). The Central and Eastern European (CEE) Electricity Markets Integration Initiative was implemented in November 2014 with the participation of the Czech Republic, Slovakia, Hungary and Romania under the multi-regional mapping (MRC) framework. In February 2015, the matching of Italy with the electricity markets of France, Austria and Slovenia was realized. Thus, the PCR project and thus the EUPHEMIA implementation have been expanded to cover approximately $85 \%$ of the trade in the European electricity markets at the beginning of 2016 .

\section{CONCLUSION}

The aim of this study is to investigate the presence / extent of market integration in European electricity markets within the framework of the objective of a European common electricity market, the legal infrastructure of which is determined by the European Commission directives on electricity. To this end, it aims to investigate short-term movements of volatility between markets and long-term matching relationships by analyzing the relationships and interactions between market prices.

The study also aims to explain inter-market interactions with a focus on market integration. In other words, the study aims to shed light not only on the problem of integration in European electricity markets, but also on the process of overall market dynamics characterized by mutual interaction.

References:

1. Veit, B. Haucap, J. and Heimeshoff, U. (2013), "Benefits of an integrated European electricity market", DICE Discussion Paper, vol. 109.

2. ENTSOE-E (2018), "Statistical Factsheet", available at: www.eepublicdownloads.azureedge.net/clean-documents/Publications/Statistics/Factsheet/entsoe_sfs2018_web.pdf (Accessed 30 Oct 2020).

3. EPDK (2010), "Electricity Market Report", available at: http://www.epdk.gov.tr/documents/elektrik / rapor_yayin/ElektrikPiyasasiRap oru2010.pdf (Accessed 30 Oct 2020).

4. PCR (2016), "Euphemia public Description", available at: www.hupx.hu/uploads/Piac \% C 3\%B6sszekapcsol\% C3\%A1s/Euphemia \% 20Public \%20Description.pdf (Accessed 30 Oct 2020).

5. Fetter, F. A. (1924), "The economic law of market areas", The Quarterly Journal of Economics, vol. 38, no. 3, pp. $520-529$.
6. Erbach, G. (2016), "Understanding electricity markets in the EU, European Parliamentary Research Service", available at: http:/ / www.easyres-project.eu / wp-content/uploads/2019/02/understanding-elecricitymarkets-in-the-eu.pdf (Accessed 30 Oct 2020).

7. Hunt, S. (2002), Making Competition Work in Electricity, John Wiley \& Sons, Hoboken, USA.

8. Bower, J. (2003), European Electricity Markets Structure and Trading, The Oxford Institute for Energy Studies, Oxford, UK.

9. Next Kraftwerke (2020), "List of power \& energy exchanges worldwide", available at: https://www.nextkraftwerke.com/knowledge/power-exchanges-list (Accessed 30 Oct 2020).

10. Pagnier, L. and Jacquod, P. (2018), "How fast canone over come the paradox of the energy transition? Aphysico-economic model for the European power grid", Energy, vol. 157, pp. 550-560.

11. Weron, R. (2006), Modeling and forecasting electricity loads and prices: A statistical approach, John Wiley \& Sons, Hoboken, USA.

Стаття надійшла до редакиї 24.10.2020 p.

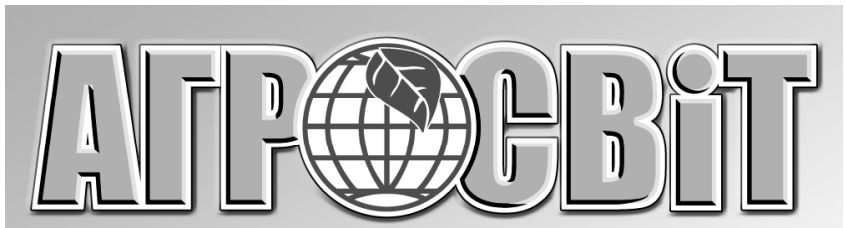

wWW. agrosvit. info

Передплатний індекс: 23847

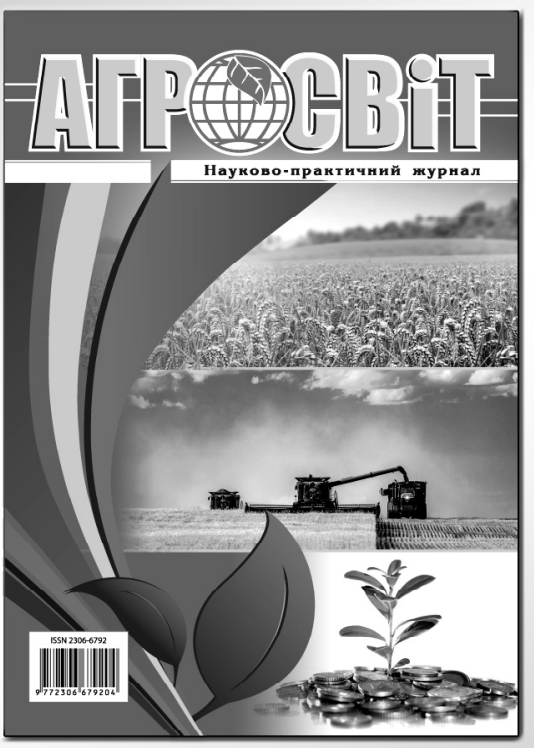

Виходить 24 рази на рік

$$
\begin{gathered}
\text { Хурнал включено до переліку } \\
\text { наукових фахових видань України } \\
\text { з ЕКОНоМІЧнИХ НАУК (Категорія «Б») }
\end{gathered}
$$

Спеціальності - 051, 071, 072, 073, 075, 076, 292 